\title{
Planning and Making the Transition to a Flipped Classroom
}

\section{Giancarla Unser-Schutz \\ Rissho University}

\section{Reference Data:}

Unser-Schutz, G. (2019). Planning and making the transition to a flipped classroom. In P. Clements, A. Krause, \& P. Bennett (Eds.), Diversity and inclusion. Tokyo: JALT.

This paper outlines the steps and process of flipping a classroom, using the author's own experience flipping a university-level English speaking class as an example. After reviewing the concept of flipping the classroom-having students engage in instruction-oriented activities such as reading and watching videos outside of class and conduct practice-oriented exercises in classthe motivations behind flipping the classroom are reviewed, followed by a basic overview of how flipping the classroom can be approached. In particular, 4 steps are described that lead readers through the planning process of flipping the classroom, with tips and ideas about how others can follow this process. Though a frank review of what was both successful and problematic, the author also provides an opportunity for others to improve upon the process.

本論では、筆者の経験に基づき、大学しベルの英会話の授業を例に用い、反転授業への道のりを段階別に概説していく。従 来教室で行われてきた教員による説明的学習を、ビテオ等を用いて目宅で行う代わりに、教室では、従来自宅で行われてきた 練習・復習課題に取り組むという反転授業の授業法の概要を述べた後、反転授業を試みることになつた動機を明記し、反転授 業に移行する方法を検討する。具体的に、反転授業の実施までに経てきた計画の4段階を詳述し、実施に当たるヒント・アイテ イアを提供する。成功した点・問題が発生した点を率直に検討することにより、反転授業への移行過程を改善する心得も提供 する。

lipping the classroom has drawn attention within the field of foreign language - education as an innovative way to improve learning outcomes (e.g., Egbert, Herman, \& Chang, 2014; Han, 2015; Sung, 2015; Webb \& Doman, 2016). In the flipped classroom, what has traditionally been assigned as homework is instead done in the classroom under instructor guidance, and formal instruction traditionally done in the classroom is completed by students outside of class using textbooks, videos, or other materials (see Figure 1). Flipped classroom models gained attention following Bergmann and Sams (2012), who used the model to teach high school chemistry but encouraged its use in second language learning. Since then, research has suggested that flipping the classroom can lead to better learning achievements in grammar skills in second language classrooms (Webb \& Doman, 2016) and improved student learning autonomy (Han, 2015). It can seem overwhelming for teachers to plan a completely new classroom model, but it does not have to be so, and this paper outlines four steps to flip the classroom following the author's own experience.

Traditional classroom:
$\begin{gathered}\text { Feacher lectures, students follow } \\ \text { along with textbook }\end{gathered}$
Students learn about new material using
videos, etc.

Figure 1. The flipped classroom model.

Teaching in a non-ESL major faculty at a mid-tier private university, I was motivated to flip by the opportunity it presents to offer more active learning activities in class. I 
specifically aimed to flip the classroom in English Speaking I/ll, a required sophomore English class focusing on conversational skills. As Kanai (2014) has experienced, students in mid-tier universities often have high "latent skills" (senzai nooryoku), but need support to develop them (p. 123). For ESL classes this means that in order to help students develop their production skills, they need a large amount of review and scaffolding (see Unser-Schutz, 2016, 2018). However, doing so often results in insufficient time for productive speaking exercises. Flipping the classroom can increase that time, as shifting review that is potentially repetitive-as some students will need it less than others-to outside the classroom allows more class time to be used for practice beneficial to all students.

The process described here is based upon the author's own experience flipping the classroom, which began in 2016, meaning that 3 years have now passed; this longterm planning appears typical when implementing the flipped classroom (O'Flaherty \& Phillips, 2015). Generally speaking, 2016 was used for planning; 2017 was used to roll out new materials; and the current year of 2018 has been primarily about refining and revising the materials. In the process there were four major steps: planning, creating, providing, and integrating. Planning entailed researching and choosing a platform for online lessons. Creating involved making actual lessons and doing test runs. Providing necessitated choosing how to present the new materials and creating space to house them. Integrating centered on planning and creating complementary classroom activities.

\section{Steps for Flipping the Classroom}

Step 1: Planning Stages

This first stage is primarily about researching and evaluating what to achieve through flipping the classroom and how that can best be done. Two important questions to consider are how best to provide lessons for the class's needs, and what are the most desirable ways for students to engage with the learning material. As flipping the classroom involves moving homework activities into the classroom, which usually represent a major portion of grades, it will also be important to consider what relationship these new out-of-classroom activities will have with grades and how they can be tracked if they are to be included as part of students' grades. It is also important to consider what kind of platforms are available for each class's needs.

Considering student engagement with materials will largely require thinking about how flipping should transform the class. In my case, there were three goals behind flipping. The first was to increase the time on and the quality of speaking and writing exercises. This meant moving review learning points out of class, but it presented a dilemma in that students were not likely to do review if it relied solely on an honor system, which was clear from my experience with previous activities. Flipping the classroom requires some monitoring of activities; ideally, the out-of-classroom activities should also have an impact on grades to encourage participation.

Second, I wanted to dynamically present review points and detailed explanations with the help of visual aids, such as charts, graphs, and figures. In order to maximize their usefulness for students, I also wanted to provide the new materials in a form that could be used not only for weekly assignments, but also for review over the semester and before exams. Although flipped classrooms have been done with a variety of platforms and materials (O'Flaherty \& Phillips, 2015), providing lessons in a form that encouraged engagement was a major concern.

Finally, I wanted to create a space where I and the students felt comfortable using Japanese to scaffold learning. Although I wanted to use English in the classroom, I had also come to feel that offering more Japanese support for difficult study points was vital to increasing students' understanding. With students who were not motivated to study, however, it was easy to slip into using Japanese for all interactions. Although it is increasingly clear that using students' first language is crucial to developing second language skills (Auerbach, 1993), it is not always easy to find balance, and developing an outside space for such interaction is one way to approach this issue.

Given these goals, creating lesson videos for students on a platform where student activity could be monitored was deemed the most appropriate format. There are many platforms available for switching the classroom, ranging from free, simple systems to more complex, proprietary systems (Table 1). If the goal is to have students watch videos with little monitoring or interaction, uploading to YouTube is an easy process (see Brook, 2011, for an example). Midway in complexity, Google Forms offers instructors the ability to embed videos within surveys, allowing monitoring of activity through the survey function. There are also open source learning management systems (LMSs) such as Moodle that provide tools such as chat boards and messaging as well as links to resources. Finally, many universities have contracts with proprietary online class programs and LMSs such as WebClass and Manaba in Japan, which offer similar services but are commonly integrated into other institutional platforms.

Each system has its own advantages and disadvantages, and a key part of this first step will be to consider what is necessary for each class's needs (see Table 1). An important consideration for me was that it not be a costly, aggressively proprietary platform. Such platforms can be problematic for several reasons, the first being that as long as they are used, costs will be continually incurred. Proprietary platforms offered by institutions are 
also problematic. Although they are free while teacher and students are at the institution, they may not be usable if the institution changes contracts or the instructor switches jobs; students are generally not able to access them after graduation or-as is the case with many textbook online systems - after the course is over, discouraging continued study. Furthermore, it is easier to share free services with instructors who might not have the same financial resources.

Given that I wanted to monitor student activity but was not looking to have all classwork online, Google Forms seemed most suited to my needs. Google Forms made it possible to provide students with lesson videos and include follow-up questions. Although it is proprietary, it is also open to the development of third-party applications and is free to use. By the end of this stage, a basic plan was in place for how to flip the classroom: Each online lesson would include a video made in PowerPoint, audio recorded with detailed English and Japanese explanations, and a few questions based on the video to confirm that students watched it. Details on how this was done can be found in Unser-Schutz (2018); see also the example in Figure 2.

Table 1. Pros and Cons of Different Platforms Available for Flipping the Classroom

\begin{tabular}{llcccccc}
\hline Platform & Basic usages & Ease & Monitoring & $\begin{array}{c}\text { Question } \\
\text { prompts }\end{array}$ & $\begin{array}{c}\text { Student } \\
\text { interaction }\end{array}$ & $\begin{array}{c}\text { Free of } \\
\text { cost }\end{array}$ & $\begin{array}{c}\text { Shareable } \\
\text { between } \\
\text { instructors }\end{array}$ \\
\hline YouTube & $\begin{array}{l}\text { Uploading } \\
\text { videos }\end{array}$ & 0 & $\triangle$ & $\times$ & $\triangle$ & 0 & 0 \\
$\begin{array}{l}\text { Google } \\
\text { Video/ } \\
\text { image- } \\
\text { embeddable }\end{array}$ & 0 & 0 & 0 & $\times$ & 0 & 0 \\
surveys & $\begin{array}{l}\text { Freeware } \\
\text { LMS }\end{array}$ & $\triangle$ & 0 & 0 & 0 & 0 & $\triangle$ \\
$\begin{array}{l}\text { Manaba, } \\
\text { WebClass, } \\
\text { etc. }\end{array}$ & $\begin{array}{l}\text { Proprietary } \\
\text { LMSs }\end{array}$ & $\triangle$ & 0 & 0 & 0 & $\times$ & $\triangle$ \\
\hline
\end{tabular}

Notes. O: Well equipped for task, $\triangle$ : Possible but not ideal, $\times$ : Not available.

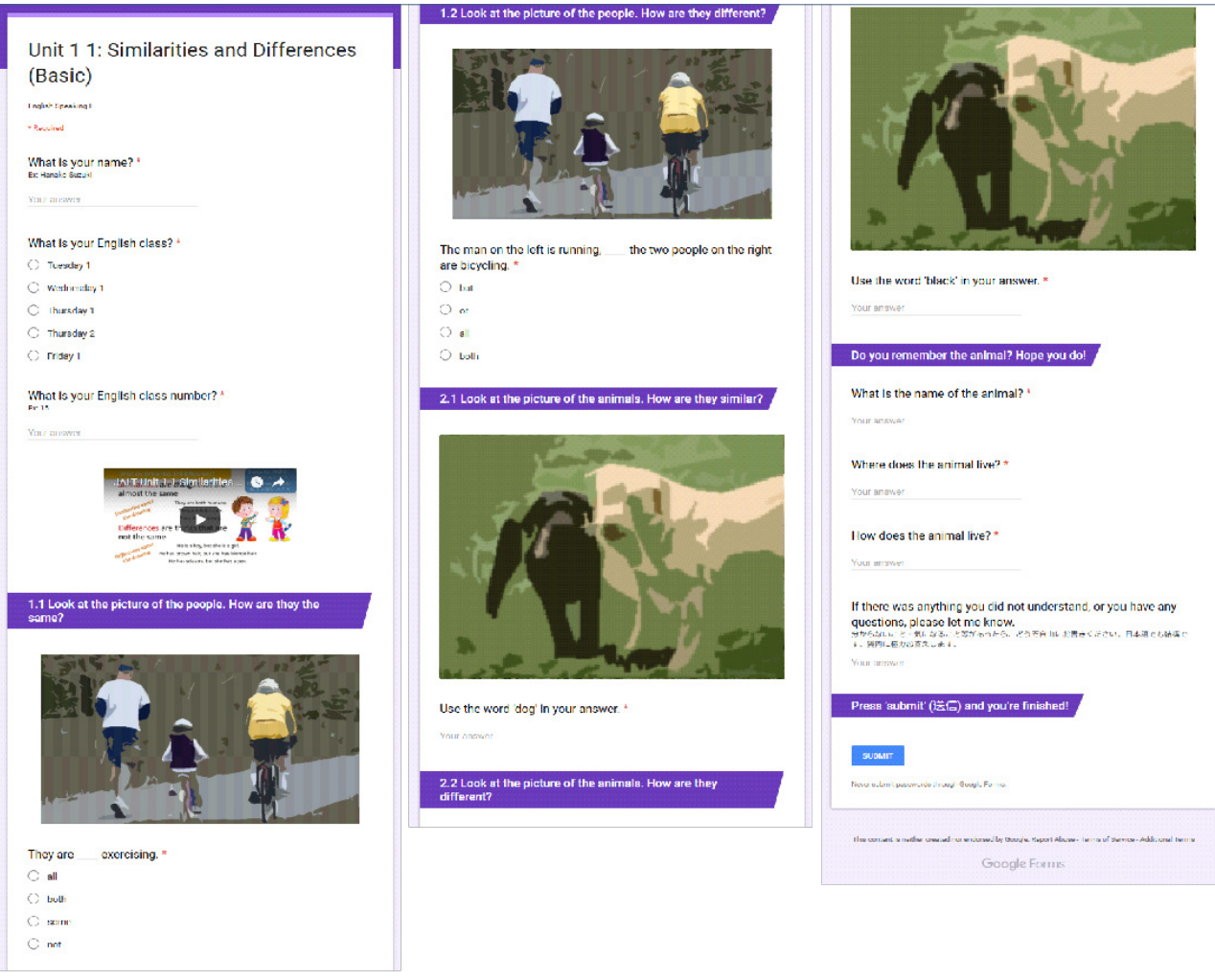

Figure 2. Example of an online lesson on Google Forms (from Unser-Schutz, 2018).

\section{Step 2: Creating Lessons}

The next step is creating the lessons. This involves three substeps: getting familiar with the platforms being used, deciding what kind of materials to include, and making and testing the actual materials. The best way to become comfortable with the platforms is to use them. Experimenting with the platforms and confirming what tools are available at an early point in the process-before becoming committed to their use and before feeling the pressure of producing something for a class-will be crucial to smoothly flipping the classroom. This can be done in a number of ways. One option is to first use the platform for relatively limited, low-stakes activities. If using Google Forms, it can be good to make 
a short online quiz to see how the submission and grading processes work before making a complete lesson.

The second substep is deciding what materials to assign for out-of-class learning. When flipping an existing course, start by going through any previously prepared materials. A good way to do this is to divide material into those lessons that involve review and those that involve introduction of learning points. Anything that requires explicit instruction is a potential lesson point to be moved out of the classroom; activities helping students practice those learning points should be done in the classroom. I went through my course's required textbook and previously created homework assignments and wrote up a list of potential video lessons. Anything requiring an explanation was added as a topic to make a lesson video, with the assumption that all video topics would require corresponding classroom activities. This process is summarized in Figure 3.

\begin{tabular}{lll}
\hline Learning material & Possible outside lessons & Possible classroom activities \\
\hline New vocabulary & $\begin{array}{l}\text { Introduction of definitions, } \\
\text { usage patterns }\end{array}$ & $\begin{array}{l}\text { Activities prompting use of new } \\
\text { vocabulary }\end{array}$ \\
Grammar & $\begin{array}{l}\text { Explicit instruction of grammar } \\
\text { points }\end{array}$ & $\begin{array}{l}\text { Writing and speaking exercises } \\
\text { using the new grammar points }\end{array}$ \\
Pronunciation & $\begin{array}{l}\text { Explicit explanation of } \\
\text { pronunciation points } \\
\text { Pistening/speaking tips and } \\
\text { Pragmatics }\end{array}$ & $\begin{array}{l}\text { Practice producing target forms } \\
\text { Targeted roleplay and student } \\
\text { interviews }\end{array}$ \\
\hline
\end{tabular}

Figure 3. Potential ways to split material when flipping the classroom.

The next substep is making the materials. How to do this will depend on which platform is chosen; going back to the platform to explore can be helpful. The activity can be as simple as a written explanation of the learning points in a text document or a PowerPoint to a more complicated video or other form that offers more interactivity. If using Google Forms, explanations of the study points can be included as text within the form itself and the survey function can be used as a way to ensure that students have read it; alternatively, explanatory videos created in PowerPoint or other software can be embedded in the Google Form (see Unser-Schutz, 2018). The former option has the advantage of being easy to create but the disadvantage of being potentially uninteresting whereas the latter is more difficult to create but more engaging.
Important components each lesson should include are explanations of the phenomenon being studied and some way to collect students' personal info (name, student number, etc.), if these online lessons are to contribute to grading. Students register to individual classes when using LMSs, but each Google Form is independent, so it will be necessary to prompt students to input this data each time. It can also be good to include questions on the material: Given that the goal is to do productive activities together in the classroom, these questions should not necessarily aim to test students' abilities, but to confirm that they have engaged with the material. One way to do this is by including something that students would not know without having done so, which could be included as one of the questions. This could be an interesting fact or something completely unrelated such as a random animal photo. For example, if studying verb conjugations, a slide about how children acquiring English as their first language overuse the third person singular $-s$ could be added, with the follow-up question, "Do 'native speakers' ever misuse the third person singular -s?" If the platform permits, including questions asking for feedback from students can also be helpful. Finally, each lesson should be thoroughly checked for bugs.

\section{Step 3: Providing Lessons}

The third step involves accessibility. Specifically, to make lessons accessible, one should plan how to explain to students about the online lesson system and where those lessons are. Handouts explaining how to do the online lessons and their relationship to classwork and grades are a good first step; it can be helpful to use class time on the first day to show students the lessons. Depending on classroom equipment, this may mean bringing in a computer or reserving a computer room. This requires some advance planning, so it is important to explicitly plan how to introduce the new formats to students.

The accessibility of the lessons will depend on the platform chosen. One of the advantages of LMSs is that they can act as a one-stop place to house classroom work. If it is a system contracted by the university and used in other classes, students may already be familiar with it. This is where proprietary contracted LMSs become useful. For other platforms, some creativity will be needed. If using YouTube, one can set up a user channel for each flipped class, thus providing students with a one-stop location. On Google Forms, each new lesson will have its own URL. Each time a lesson is assigned, it is necessary to provide students with the URL, perhaps by emailing links to students or including the links in weekly handouts. The forms can also be housed on Google Classroom, a free platform in the Google Apps for Education suite. The user agreement 
requires the school to create an account before teachers can use the applications, but the platform will likely become increasingly popular.

Google Forms can also be housed on a homepage on Google Sites, which allows Google users to create free websites with little HTML knowledge. By posting the links there, the site becomes a one-stop location that students can bookmark and come to weekly to look for lessons, rather than having to provide them with multiple, potentially confusing new URLs each week. Finally, for videos, it can also be worthwhile to provide students with handouts to make it easier to follow lessons and take notes; if the videos are made using slideshows, a print out of the slideshow is likely sufficient.

\section{Step 4: Integrating Lessons and Classroom Activities}

The final step is to plan in-class activities to follow up on the assignments. When switching an existing course, it can be productive to look at what materials are left after creating the lessons: These activities should be done in class. For example, if students were assigned a vocabulary lesson, I provide activities that require the use of the new vocabulary, typically reading and responding to short texts using the target words. Writing and speaking exercises are also planned with the grammar and vocabulary from the online lessons in mind. One option is having students interview each other, using questions prompting the studied forms. It is most important to make sure that anything studied online is clearly addressed in class; failure to do so will result in lost opportunities to follow up on the lessons and will not fully draw upon the potential of the flipped classroom.

\section{Effect of Flipping the Classroom}

Including the planning stages, it took approximately 3 years to fully flip my classroom. Substantially less class time is now spent reviewing material; the majority of class time is allotted to group work. Previously, it had often been unclear to students how to do the homework; this would often only be discovered after asking students why they had not done assignments. Because the exercises are now done in the classroom together, I can immediately attend to any issues; students also support and assist each other. I receive more feedback from students now, as they frequently give comments when submitting the online lessons. Students may feel more comfortable doing this through the online lesson system as it feels easier than talking with teachers directly. Willingness to communicate has been shown to be higher in cases of lower social presence in online courses (Le, Cunningham, \& Watson, 2018). It has become easier to deal with problems in a prompt fashion, and students have also used the lessons as an opportunity to ask for advice (see Example 1), making them a useful communication channel.

Example 1. Student comment on a prefixes lesson: Hoka no re ya un ga tsuku mono shiritai desu [I want to know other ones that re and un can attach to].

The most frequent problems have been technical. Previous research suggests that students are quick to adapt to flipped classrooms (overviewed in O'Flaherty \& Phillips, 2015), but students' technical skills vary, and some are not comfortable with online materials. Many students do the online lessons using their smartphones. Although Google Forms functions on smartphones, the lessons do not always display well. For many students, these online lessons are the first time they are working in English on a computer, and they are not always aware of differences between Japanese and English computing. Some students fail to understand the difference between the half- and fullwidth forms of symbols, but some of the online lessons require students to input text exactly following a preset answer. For example, the half- and full-width commas-"," and “, ”, respectively-look similar, but register as different forms. This has required some unexpected troubleshooting beyond the normal purview of ESL.

Regarding instructor technical issues, privacy settings and accessibility must be kept in mind. Because students will be submitting identifying information, it is important to fully understand how this information will be collected by the system. Security issues have been a concern of other teachers at faculty presentations on this project. Google Forms allows all the previous results to be visible to participants after submitting their own responses; this can and should be disabled. It is also important for the teacher to confirm the accessibility of the lessons by viewing them as a student. Students have occasionally reported bugs, usually with more advanced uses of Google Forms. More complex setups will have more potential problems. There have also been complaints about audio problems, usually related to recording using PC-internal mics, which are often low quality.

Anecdotally, student reception during the 1st year (starting April 2017) was generally positive, but there were some problems. Some students were uncertain how to do the lessons and unexpected issues-like the half-width/full-width issue-arose. Testing did not always remove all bugs, which discouraged some students. However, student response was generally positive, which is likely because it was explicitly explained that the online lessons affected grades, an understanding reinforced through providing students with feedback on the lessons. By the 2 nd year, most of these issues were 
addressed, and there have been very few systematic bugs to grapple with; it has also become easier to predict and respond to possible issues before they occur.

I have received no major complaints and student response continues to be positive; overall students seem to enjoy doing classroom activities together, as some have noted in course evaluations. Students have also commented that the lessons have helped their understanding (see Examples 2 and 3). Although students have written in class evaluations that there is a lot of homework-students watch between three and five videos, 3 to 5 minutes in length each, plus need time to do the follow-up questions-the average reported weekly homework time in the most recent Fall 2018 semester was 60 minutes, on target for the out-of-class work expected of a 1-credit, 15-class language course. One student commented explicitly that although the lessons might be long, they were useful.

Example 2. Student comment on a simple past endings lesson: D no hatsuon ni wa bunrui ga shikkari aru to rikai dekita [I now understood that there are real categories with the pronunciation of $d$ ].

Example 3. Student comment on a syllable stress lesson: Kore kara wa tango no kyoojaku ni mo chuui shite tango o kiitemitai desu [From now on I want to pay attention to the strength of words].

\section{Conclusions}

As Song et. al (2017) have noted, there is still insufficient research on designing and implementing flipped classrooms, and this case study contributes to that much-needed literature. Although four steps were described here, in some cases it may be necessary to move the steps forward concurrently and move between them to effectively flip the classroom. Choosing platforms and planning lessons is a codependent process; what kind of lessons one plans will affect what platform is best and vice versa. Taking the time to assess what the class requires is crucial, which means being realistic. Some things will not go as easily as hoped. In my case, the quality of recordings has occasionally been problematic, and improving audio quality - by rerecording the videos using highquality mics-has been time-consuming. Objectively measuring the benefit of flipping the classroom remains an important task, which I will address through student surveys in 2019. Even with these caveats, I believe flipping the classroom has proven to be rewarding and worth the time commitment.

\section{Bio Data}

Giancarla Unser-Schutz is an associate professor at Rissho University. She is currently interested in how to improve motivation and interest amongst students in nonEFL-specialist faculties. She also conducts research outside of EFL on the linguistic characteristics of manga as well as Japanese naming practices. Her publications may be found at http://rissho.academia.edu/GiancarlaUnserschutz/.<giancarlaunserschutz@ris. ac.jp>

\section{References}

Auerbach, E. R. (1993). Reexamining English only in the ESL classroom. TESOL Quarterly, 27(1), 9-32. https://doi.org/10.2307/3586949

Bergmann, J., \& Sams, A. (2012). Flip your classroom: Reach every student in every class every day. Washington, DC: International Society for Technology in Education.

Brook, J. (2011). The affordances of YouTube for language learning and teaching. Hawaii Pacific University TESOL Working Paper Series, 9(1, 2), 37-56.

Egbert, J., Herman, D., \& Chang, A. (2014). To flip or not to flip? That's not the question: Exploring flipped instruction in technology supported language learning environments. International Journal of Computer-Assisted Language Learning and Teaching, 4(2), 1-10. https://doi.org/10.4018/ ijcallt.2014040101

Han, Y. J. (2015). Successfully flipping the ESL classroom for learner autonomy. NYS TESOL Journal, 2(1), 98-109.

Kanai, M. (2014). 中堅層大学における数理社会学教育一授業内容例と学生の反応一 [Educational sociology of mathematics at mid-tier universities: Examples from course content and students' reactions]. 理論と方法 [Sociological Theory and Methods], 29(1), 123-130. https://doi.org/10.11218/ ojjams.29.123

Le, T. V., Cunningham, U., \& Watson, K. (2018). The relationship between willingness to communicate and social presence in an online English language course. The JALT CALL Journal, 14(1), 43-59. Retrieved from https://jici.jaltcall.org/index.php?journal=JALTCALL\&page=article\& op=view\&path\%5B\%5D=126\&path\%5B\%5D=148

O'Flaherty, J., \& Phillips, C. (2015). The use of flipped classrooms in higher education: A scoping review. Internet and Higher Education, 25, 85-95.

Song, Y., Jong, M. S. Y., Chang, M., \& Chen, W. (2017). Guest editorial: "HOW” to design, implement and evaluate the flipped classroom?-A synthesis. Educational Technology \& Society, $20(1), 180-183$.

Sung, K. (2015). A case study on a flipped classroom in an EFL content course. Multimedia-Assisted Language Learning, 18(2), 159-187. 
Unser-Schutz, G. (2016). Improving a university English program: Issues from one case study. In P. Clements, A. Krause, \& H. Brown (Eds.), Focus on the learner (pp. 14-21). Retrieved from http:// jalt-publications.org/sites/default/files/pdf-article/jalt2015-pcp_003.pdf

Unser-Schutz, G. (2018). Flipping the classroom with Google Forms and online video lessons. In P. Clements, A. Krause, \& P. Bennett (Eds.), Language teaching in a global age: Shaping the classroom shaping the world (pp. 334-341). Retrieved from http://jalt-publications.org/sites/default/files/ pdf-article/jalt2017-pcp-044.pdf

Webb, M., \& Doman, E. (2016). Does the flipped classroom lead to increased gains on learning outcomes in ESL/EFL contexts? CATESOL Journal, 28(1), 39-67. 